POLSKA AKADEMIA UMIEJĘTNOŚCI

TOM XIII

KULTURA SŁOWIAN. ROCZNIK KOMISJI KULTURY SŁOWIAN PAU

2017

DOI $10.4467 / 25439561$ KSR.17.012.7882

JÓZEF KUFFEL

Uniwersytet Jagielloński

Kraków

\title{
КИРПИЧ ИВАНА ГРОЗНОГО ИЛИ МОСКОВСКИЙ ВАРИАНТ СИМФОНИИ
}

\author{
A BRICK OF IVAN THE TERRIBLE \\ OR THE MOSCOVITE VARIANT OF SYMPHONY
}

\begin{abstract}
Streszczenie
W tytule artykuł nawiązuje do latopisarskiego podania o cegle, która spadła na głowę Iwana Groźnego podczas zwiedzania nowo zbudowanej cerkwi katedralnej Wołogodzkiego Kremla. Przywoływane są polemiki i częstokroć wzajemnie sprzeczne poglądy wyrażane w środowiskach historyków, publicystów, pisarzy, a nawet mnichów w odniesieniu do osobowości i roli pierwszego władcy moskiewskiego koronowanego na Cara Wszech Rusi. Szczególnie pomocne dla scharakteryzowania owej różnorodności interpretacji i ocen okazały się prace wybitnego badacza staroruskiego społeczeństwa i państwowości Stiepana Wiesiołowskiego.

Na początku swego panowania Iwan IV brał aktywny udział w kodyfikacji życia i liturgii Cerkwi Moskiewskiej, zwołując w Moskwie w 1551 r. Sobór Stu Rozdziałów (Stogław). To wydarzenie - mające z założenia mieć rangę porównywalną do soborów Kościoła greckiego, w którym uczestniczyli zarówno Car, jak i Metropolita Moskwy i Wszech Rusi Makary - stanowiło wyraz dążenia państwa moskiewskiego do symfonii Cerkwi i władzy carskiej - deklarującego wolę kontynuacji tradycji bizantyńskiej.

Św. Maksym Grek identyfikujący się z kierunkiem mistyczno-ascetycznym w prawosławnym monastycyzmie - współcześnie nazywanym hezychazmem - przybył do Moskwy w marcu 1518 r. Atonicki Starzec był apologetą i w pewnym sensie stróżem idei bizantyńskiej na Rusi. W swoich pouczeniach, posłaniach i komentarzach - w oparciu o teksty patrystyczne chrześcijaństwa wschodniego - utrzymywał, że prawdziwa symfonia władzy państwowej i cerkiewnej nie jest możliwa bez przemiany natury ludzkiej każdego członka Kościoła. W bizantyńskiej i staroruskiej tradycji osiągnięcie takiego stanu określano mianem przebóstwienia (gr. theosis).
\end{abstract}


Iwan IV w listach adresowanych do jednego ze swych dawnych doradców i krewnego, księcia Andrieja Kurbskiego, który wyemigrował na Litwę, wyraził własny pogląd na temat prawosławnej władzy carskiej. Pomimo deklaracji wierności prawosławiu de facto odrzucił on tradycję bizantyńską, czego wyrazem stało się m.in. powołanie opryczniny i stracenie metropolity Filipa.

W artykule wysuwa się i uzasadnia tezę o tym, że istota osobistej tragedii Iwana IV oraz niespełnienie nadziei w nim pokładanych stanowiły rezultat nieposłuszeństwa cara wobec atonickiego świętego starca. Brak mądrości pokory i nieprzyjęcie pouczenia o tym, że bez ontologicznej przemiany (gr. metanoia) każdego z członków prawosławnej teokracji (w tym również cara, który dla Cerkwi miał stać się ikoną Chrystusa łagodnego i pokornego sługi) niweczy prawosławną symfonię władzy, a tym samym uniemożliwia Rusi realizację dziejowej misji III Rzymu.

\section{Summary}

The title refers to a legend about a brick that fell on Ivan IV head while exploring the newly built Cathedral Church of Vologda Kremlin. In this article is shown polemics and mixed responses - in environmental historians, publicists, writers and even monks - to the personality and the role of the first ruler to be crowned as Tsar of All the Russias. Especially the variety of views is presented in works of Stephan Veselovsky who is a researcher of Old Russian society and state.

At the beginning of his reign Ivan IV confirmed the position of the Orthodox Church with the Council of the Hundred Chapters [The Stoglavy Sobor] that was held in Moscow in 1551. This event, with the participation of Tsar and Metropolitan Macarius, was an expression of the desire of Muscovite state to symphony of Orthodox Church and Tsarist power.

Maximus the Greek, identified himself with the mystical-ascetic trend in the Orthodoxy monasticism called Hesychasm, came to Moscow in March 1518. Hagiorite Elder (Staretz) was a teacher of the Byzantine idea on Russia. He taught on the basis of The Holy Fathers of Eastern Christianity that true symphony is not possible without transformation of human nature. In the Byzantine and Old Russian tradition this state was termed as deification.

Ivan IV in the correspondence to one of his advisors, Prince Andrei Kurbsky, who defected to the Lithuanians, expressed his own view about Orthodoxy Tsarist power. He rejected the Byzantine tradition. One expression of this was, among other things, the creation of the Oprichnina and the execution of Metropolitan Philip.

The article promotes the thesis that the essence of personal tragedy and fulfillment of hopes pinned on Ivan IV is the result of disobedience to Saint Hagiorite Elder who warned that without transformation (gr. Metanoia) of each member of the body of the Orthodox Theocracy the idea of the Third Rome is unachievable.

Słowa klucze: symfonia, hezychazm, Maksym Grek, Iwan Groźny

Key words: symphony, Hesychasm, Maximus the Greek, Ivan the Terrible 
Житие и чудеса прп. Нила Сорского, напечатанное Гелианом Прохоровым, было отредактировано в нач. ХІХ в. на основании более древних текстов, составленных иером. Никоном (впоследствии иеросхим. Нилом) Прихудайловым.

Особенно интересное для нашей темы Чудо второе:

«Егда благовърный царь и великий князь Іоаннъ Васильевичь, нарицаемый Грозный, приходиль на Бълоозеро во обитель преподобнаго Кирілла богомоленія ради, тогда пріиде и въ пустыню, или скитъ, къ преподобному Нилу Сорскому Чудотворцу. И совершивъ молебное пъніе при гробъ его, видъ пустынное оное мъсто уныло и вельми душеполезно, ко умиленію же и слезамъ приводящо, прослави Бога и, угодника Его житію почудився, повель же церковь каменную отъ своихъ царскихъ сокровищь воздвигнути на мъстђ томъ.

Въ то время явися ему преподобный Ніль и не повелъ ставити церкви каменныя, ни же излишнему украшенію быти въ церквахъ, проувъде бо преподобный, якоже нъцыи ръша, оть разбойникъ грабленіе быти имущее. Азъ же мню, яко не мнЊе и сего ради не благослови Богъ и угодникъ Его отъ царя сего построеннъй быти церкви или храму, понеже сей, аще и благоверенъ бъ, но премногія крови пролія и многія великія святыя мужи умучи и умертви, якоже исторія яже о немъ ясно являетъ. И что дивно: аще и пророку и боговидцу Давыду, о немже Самъ Богъ свидьтельствова, глаголя: «Обрьтохъ Давыда, раба Моего, мужа по сердцу Моему» (Пс. 88, 21), - и егоже кротости и незлобію вси святые дивляхуся, - аще сему, глаголю, не бъ позволено создати дому имене Господня, речено бо бъ къ нему отъ Господа: не созиждеши ты дому Моего, понеже многія крови пролияль еси, но сынъ твой той созиждетъ домъ имени Моему» (ср. 1 Пар. 22,8-10), сице убо и зде бысть» ${ }^{1}$.

В примечании отмечено, что весь последний абзац, являющийся толкованием смысла запрещения Грозному Царю постройки каменной церкви, перечеркнут и отчасти стерт в рукописи Российской национальной библиотеки (РНБ, собр. Кирилловского историко-художественного музея-заповедника, № 31). Это свидетельствует о том, что кто-то его заклеивал и, может быть, именно тогда на полях была помещена приписка:

«Сія причина несправедлива: это написаль іеромонахъ Ніконъ по своему мнънію, который и церкви деревянныя разориль, и святое мъсто, насыпанное руками преподобного Ніла, раскопаль. Ибо царь Іоаннъ Василевичь много воздвигъ каменныхъ цҺрквей и монастырей, которые и до днесь существуютъ. Но подлинно преподобный провидълъ, что будутъ находити воры, и ради нищеты и смиреномудрія монашеского, как видно из Устава его, возбранилъ царю строеніе каменной церкви, а не потому, аки бы царь кровей былъ. Ибо и мы вси грьшни и нечисти предъ Богомъ, хотя и хвалимся своей лицьмърнною святостію»².

1 Житие и чудеса прп. Нила Сорского в списках ХІХ в., подготовка текстов Г. М. Прохорова [в:] Преподобные Нил Сорский и Иннокентий Комельский. Сочинения, Изд. подг. Г. Прохоров, Санкт-Петербург 2005, с. 415-416.

2 Прим. 16, там же. 
Перед нами отголосок полемики и неодназначного отношения к личности и исторической роли первого русского царя в монашеской среде Белоозерья приблизительно времен издания Истории государства Российского Николая Карамзина. В воспроизведении фактов эпохи Грозного историограф во многом следовал опальному князю Андрею Курбскому. В свою очередь его отношение к историческим фактам сильно повлияло на следующие поколения не только исследователей, но также писателей и художников.

В Обзоре мнений историков об опричном дворе Царя Ивана Степан Веселовский приводит критические оценки выдающихся историографов XIX в.: Михаила Погодина, Сергея Соловьева и Василия Ключевского. Но есть и крупные авторитеты, которые в это время пытаются с довольно большим успехом реабилитировать Иоанна IV, среди них особенно значимые - Константин Кавелин и Сергей Платонов.

Из публицистов особого внимания заслуживают положительные высказывания наиболее известного литературного критика первой половины столетия Виссариона Белинского о силе характера железного и ума высокого ${ }^{3}$ Ивана.

Не разделяя энтузиазма апологетов Грозного, Степан Веселовский следующим образом мотивирует неожиданную, казалось бы, вспышку положительного отношения к основателю опричнины у представителей разных, часто противостоящих друг другу, кругов общества:

«По вопросу об опричнине Кавелин (...) писал: «это учреждение, оклеветанное современниками и непонятное потомству (...) Опричнина была первой попыткой создать служебное дворянство и заменить им родовое вельможество, на место рода, кровного начала, поставить в государственном управлении начало личного достоинства.

(...) но в эпоху реформ Александра II и нарождения «мысленного пролетариата» Писарева эта идея широкой дороги, открытой талантам, независимо от происхождения, оказалась как нельзя более кстати и обеспечила успех мнению Кавелина в кругах либеральной и революционной интеллигенции. С другой стороны, кавелинское восхваление самодержавия находило самый благожелательный успех в кругах консерваторов и реакции» 4 .

Степан Веселовский в своих критических эссе 40-х годов - по поводу исторической трилогии Иван Грозный Валентина Костылева и постановки одноименной пьесы Алексея Николаевича Толстого (кстати, оба автора удостоились почетной сталинской премии), - отважно ратует за независимость ученого 5 .

${ }^{3}$ Ср. С. Веселовский, Обзор мнений историков об опричном дворе Царя Ивана [в:] его же, Московское государство XV-XVII вв. Из научного наследия, Москва 2008, с. 197.

${ }^{4}$ Там же, с. 198.

${ }_{5}^{5}$ См. С. Веселовский, По поводу трилогии тов. Костылева и возникшей о ней полемики; его же, О драматической повести «Иван Грозный» А.Н. Толстого; его же, Московское государство..., с. 141-187. 
Сознавая свою отчужденность, исследователь общественно-государственных порядков Древней Руси - со свойственной ему остроумной иронией - приветствует направление развития официальной историографии своего времени: «Итак, реабилитация личности и государственной деятельности Ивана есть новость, последнее слово и большое достижение советской исторической науки» ${ }^{6}$.

Всего лишь двумя десятилетиями раньше Георгий Федотов пишет в эмиграции свою знаменитую монографию Святой Филипп, митрополит Московский․ Зверскому террору Грозного он противопоставляет в ней кроткий облик святителя, указывая на него (весьма убедительно) как на поборника православной идеи симфонии. В годы самостоятельного царствования Иоанна IV (1545-1584) московскую митрополичью кафедру занимали два канонизированных русской Церковью святителя: Макарий (1542-1563) и Филипп (1566-1568). Первый составитель Великих Четьих Миней и участник Стоглавого собора - был выразителем симфонии в действии, второй - священномученик и бывший игумен Соловецкого монастыря - стал ее исповедником.

Проф. Ханна Ковальская-Стус в своей монографии о древнерусской культуpe XI-XVI вв. убедительно обосновывает тезис о стремлении Церкви Московской к идеалу симфонии и о симптомах оторванности от этой традиции:

«Стоглав доказывает, что Церковь на Руси выступила за нерушимость византийского и древнерусского образцов. Свидетельствуют об этом многократные ссылки в нем на Святых Отцов, императоров Константина, Юстиниана и князя Владимира. Эта модель, однако, была определяема в юридических терминах, навязанных Иваном IV»8.

Выразителем византийской идеи на Руси был прп. Максим Грек, прибывший с Афона в Москву в 1518 г. по призванию родителя первого русского царя. Он, кстати, обращал свои послания и к нововенчанному царю и к помазавшему его св. миром митрополиту.

В Послании к благоверному царю и великому князю всея России Иоанну Васильевичу мы читаем:

«(...) Есть много таких свойств, которыми благочестно царствующие на земле уподобляются небесному Владыке, каковы - кротость и долготерпение, попечение о подчиненных, щедрое расположение к своим боярам, преимущественно же правда и милость, и то, чтобы не презирать обижаемых, но с великим человеколюбием и божественной ревностью возбуждать себя к отмщению за них. Это делает начальствующих подобными Богу, и державу их не только утверждает и сохраняет в глубоком мире и тишине, но и прославляет их знаменитыми победами, низводя

${ }^{6}$ С. Веселовский, Обзор мнений историков..., с. 213.

7 См. Г. Федотов, Святой Филипп, митрополит Московский, Париж 1928.

${ }^{8}$ H. Kowalska, Kultura staroruska. Tradycja i zmiana, Kraków 1998, c. 221. 
на них свыше помощь десницы Вседержителя, которая покоряет под ноги их всех сопротивных. Доказательством сего (...) в Новом же, более совершенном, Завете Константин, Великий и первый из христианских царей, Феодосий, также Великий и благочестивый, и внук его Феодосий, нареченный Младшим, и многие другие благовернейшие и праведнейшие цари, которые великой своей праведностью, благоразумьем и прилежным попечением о подчиненных благоугодили Царствующему в вышних, всегда пребывали в глубоком мире и тишине и одержали преславные победы над варварами, будучи покрываемы и укрепляемы всемогущей десницей Вышнего. Но это [всегда] происходит следующим образом!

(...) Ты же, благочестивейший и достохвальный самодержец всея России, которому вверен Самим Вышним скипетр преславного царства, - кого другого можешь ставить себе всегда в образец, как не Самого только Царствующего на небесах и святые заповеди Того, который один страшен и всесилен (...). Если на Него одного возложишь все свое упование и по Его спасительным заповедям и законам будешь устроять вверенное тебе царство, и будешь всегда творить суд и правду посреди земли (см. 2 Пар. 9, 8. Иер. 23, 5; 9, 24, Пс. 73, 12) как (сие) написано [в Священном Писании], то ты во истину блажен и треблажен не только в будущем, но и в настоящем веке: ибо всегда будешь сохраняем Им во всякой безопасности, мире, здравии, славе, благословении и духовном разуме.

Ничего да не предпочтешь правде и суду Царя Небесного, Иисуса Христа, Господа и Бога твоего, ибо ничем другим не возможешь так благоугодить Ему и привлечь Его милосердие и благотворения на твою богохранимую державу, как твоею правдою к подчиненным и праведным судом, также щедротами и кротостью ко всем, вообще, неимущим. Хороши, воистину, и весьма спасительны молитва и пост, ибо постом погашаются и умерщвляются плотские страсти и очищается ум, молитва же соединяет трезвенно молящегося с Богом, духовно присвояет Ему и делает богоподобным» ${ }^{9}$.

Из этого следует, что православный самодержец в исполнении своего призвания должен уповать на Христа как образец истинного Царя, т.е. устроить свое царство по заповедям Христовым, но и следовать Его примеру по отношению к вверенным подданным (среди заповедей любовь есть первая). Но Святогорец однозначно выступает как духовный отец (Старец). Свой призыв к выполнению царского призвания - творению суда и правды посреди земли русской - он обуславливает духовной жизнью (в согласии с учением Святых Отцов, особенно Лествичника), т.е. победой над страстями и очищением ума (в этом самое верное орудие есть пост) и молитвой, которая соединяет с Богом. Исполнение этих наставлений он духовно присвояет уму (дар Духа Святого, о действии которого свидетельствуют добродетели).

Выше было сказано о правде и праведном суде, их исполняет только праведный и бесстрастный человек; о кротости, великодушии и вообще об образце

9 Преподобный Максим Грек, Духовно-нравстренные слова, Слово XXVIII, Свято-Троицкая Сергиева Лавра 2008, с. 310-312. 
Христовом и Его заповедях. Прп. Максим выступает здесь не как моралист, а его поучение не преследует этический идеал. В своих наставлениях православным самодержцам он утверждает, что - венчанные на царство приближвются к образу небесного Царя Христа благодаря соединению с Богом. Как условие для осуществления этого онтологического идеала необходим особый вид молитвы. Только человек трезвенно молящийся - реально соединяется с Богом и таким образом присваивает Его дары (св. Григорий Палама определяет их понятием: «Божьи энергии») и становится богоподобным (т.е. свои человеческие энергии синхронизирует с Божьими).

Прилагательное «трезвенная», стоящее рядом со словом «молитва», сразу однозначно определяет дискурс, в который вписывается учение Святогорца - это есть традиция византийского исихазма. Оно происходит от одного из основных понятий исихастов «трезвение» (гр. непсис) и обозначает цельное сосредоточение человеческих энергий направленных на сотрудничество с Божьими энергиями. В словаре исихастской антропологии оно имеет близкие значения, такие как: «бдение», «внимание», «хранение ума и сердца» ${ }^{10}$, но все они относятся к такому аспекту умного делания, в котором отражены состояние и действия человека, открытого Божьим действиям. Тут уже происходит взаимодействие энергий, которое определяется как синергия.

Богоподобие есть следствие Богообщения, т.е. принятия в себя Божьих энергий и синхроизация с ними всего человеческого: наших чувств, желаний, решений, творчества, отношений к ближним и всему внешнему миру, это также касается политики ${ }^{11}$. Но в первую очередь это должно осуществляться на бытийном уровне всей человеческой природы, и поэтому мы и говорим тут об онтологии, а не об этике.

Но, кажется, Иоанн IV, для которого точкой отправления было православное благочестие и законодательство Третьего Рима, в своих писаниях перенес дискурс в плоскость нравоучения и правосудия.

«Сам Он [Царь Небесный] есть по естеству весь Благость, весь Правда, весь Милость, весь Щедрость ко всем вообще живущим на земле; таким же Он желает,

${ }^{10}$ См. J. Kuffel, Hezychazm Rusi Moskiewskiej; Metoda interpretacji na podstawie wybranych zabytków literatury przekładowej i oryginalnej, Kraków 2013, c. 103.

${ }^{11} \mathrm{Cp}$. понятие «политический исихазм» в значении, употребляемом Г. М. Прохоровым. См. Г. Прохоров, Исихазм и общественная мысль в Восточной Европе в XIV в. [в:] Труды Отдела древнерусской литературы, т. 23, Электронные публикации Института русской литературы (Пушкинского дома) РАH, http://lib.pushkinskijdom.ru/Default.aspx?tabid=8453, дост. 20.11.2015, а также С. Хоружий, Исихазм и «политический исихазм»: к уточнению понятий, Институт Синергийной Антропологии. Библитека, http://synergia-isa.ru/wp-content/uploads/2012/05/hor_polit_ isikhasm.pdf, дост. 20.11.2015. 
чтобы были и царствующие на земле, ибо царь есть не что иное, как живой и видимый, то есть, одушевленный образ Самого Царя Небесного (...).

(...) Постарайся же, о благочестивейший государь, быть другом Царя и Владыки всех, Иисуса Христа и Бога твоего и человеколюбием, и благостью и правосудием прославь Его на земле чрез земное и временное сие начальство, чтобы и Он соответственно прославил тебя Божественною Своею славою на земле и на небесах (...).

Благочестивейший государь и самодержец! Я должен высказать пред царством твоим всю истину, именно, что бывшие в последнее время у нас, греков, цари не за что иное преданы общим всех Владыкою и Творцом уничижению и погубили свою державу, как только за великую их гордость и превозношение, за иудейское сребролюбие и лихоимство, победившись которыми они неправедно грабили имения своих подчиненных, презирали своих бояр, живущих в скудости и лишении необходимого, и обиду вдовиц, сирот и нищих оставляли без отмщения. За все это и тому подобное пришел на нас, окаянных, гнев Праведного Судии, и теперь мы скитаемся, будучи оставлены, в голоде и жажде и в наготе и находимся у всех в поношении и гонении.

(...) Ты же, благочестивейший царь и государь, не последуй сему, но, как научен ты Самим Вышним и Его спасительным законом и заповедями, так и устраивай потребное и полезное для своих подчиненных, со всякою правдою и благостью, и царским разумом. Состоящего при тебе преосвященного митрополита и боголюбивых епископов сподобляй всякой чести и береги их, как посредников между Богом и людьми [ходатаев к Богу и человекам], непрестанно молящихся о твоем богохранимом царстве и святыми своими молитвами умоляющих Небесного Владыку, когда мы, как люди, прогневляем благость Его различными своими прегрешениями. Так почитай их и береги, и что они будут советовать тебе на пользу твоей богохранимой державе, в том слушай их, ибо, слушая их, слушаешь Самого Спасителя и Царя твоего Иисуса Христа, по божественному Его определению: «слушаяй вас, Мене слушает, а отметаяйся вас, Мене отметается и пославшаго Мя» (Лук. 10, 16). Видишь ли, благочестивейший государь, куда восходит оказываемая боголюбивым архиереям честь, также как и бесчестие! Страшно это слово, о благочестивейший государь, и достойно всякого храненья и соблюдения, если оказываемое нами архиереям послушание или ослушание относится к Самому Вышнему» ${ }^{12}$.

В Послании к преосвященнейтему Макарию, митрополиту всея России Старец возносит молитву за митрополита и царя:

«Господи Иисусе Христе! Сподоби и нас этой благодати, чтобы приносить Тебе такое славословие молитвами архиерея Твоего, нашего же господина и владыки Макария. Соблюди его, Господи, на многие лета для благоверного и Христолюбивого царя, верного раба Твоего, государя нашего великого князя всея России

12 Преподобный Максим Грек, Духовно-нравстренные слова, Слово ХХVIII.., с. 313-316. 
Иоанна Васильевича. Соблюди их обоих, Владыко, на многие лета и даруй им в мире и во всяком утверждении пасти благоверное достояние Твое по Твоим спасительным заповедям: одному даруй апостольски и без стеснения обильно учить и советовать царю Твоему угодное и любезное Тебе, и что содействует к исправлению и утверждению православных людей Твоих, а другому даруй с благопокорностью слушать и принимать архиерейские советы и наставления и исполнять их делом, - чтобы чрез обоих прославлялось всесвятое имя Твое пред всеми окрестными народами. Пусть все достоверно узнают о них, что насколько они воистину благочестивы и православны, настолько же и правдивы и милостивы ко всем вообще подчиненным, в особенности же к нуждающимся в милости и заступлении сиротам и вдовицам, к обижаемым со стороны бесчеловечных лихоимцев нищим и убогим, также к прибывающим из других стран иноземцам, к числу которых принадлежу и я ${ }^{13}$.

Прошение о митрополите и царе - это и есть молитва о симфонии для Московского царства. В молитве этой выявляются две основные функции служения первоиерарха Церкви: молитвенная, в том числе литургическая, для всех православных Руси, и учительская, особенно как наставника - советника царя. В их взаимоотношениях царь должен благопокорно слушаться этих навставлений, принимать и исполнять делом.

Советы митрополита согласны воле Божьей (т.к. он советует о вещах Богу угодных). Прп. Максим в предыдущем абзаце прославлял добродетели митр. Макария, считая его:

«Ревнителем этих боговдохновенных блаженных мужей [Святых Апосолов и равноапостольных архиереев] - не подумай, прошу твою святыню, что я это говорю из ласкательства - в нашем последнем роде явился ты, преподобнейший, который богоугодно и равноапостольно правишь кормилом святой митрополии Московской и всея России» ${ }^{14}$.

Митрополит советует царю то, что способствует утверждению и исправлению православных. Оба столпа симфонии служат именно этой цели. Поэтому между ними должно царствовать полное согласие, как между Отцами Вселенских Соборов, на которые только что автор ссылался. Кроме того, отношения митрополита и царя - как отца и духовного чада - служат миссии православия в мире. Но Старец призывает мерить благочестие и православие митрополита и царя правдивостью и милостью ко всем подданным и в особенности к самым беспомощным: обижаемым, сиротам, убогим и иностранцам.

Слова «правда», «правдивость» и, соответсвенно, «правдивый» сродны (особенно в этом контексте, где они выступают вместе с прилагательным «ми-

13 Там же. Слово ХХIX..., с. 321-322.

14 Там же, с. 320-321. 
лостивый») понятию «праведность». Это не правосудие, а скорее проявление святости. Неслучайно синоним святого - праведник. Речь, конечно, идет о правде Божьей, носителей которой на земле именуют праведниками.

В своем первом пространном послании от 5 июля 1564 г., формально адресованном к князю Андрею Курбскому, а на самом деле «во всей великой России государство против крестопреступников», написанном за полгода до введения опричнины, выражена чрезвычайно простая философия царской власти:

«Почему же ты презрел слова апостола Павла, который сказал: «Всякая душа да повинуется владыке, власть имеющему; нет власти кроме как от Бога: тот, кто противится власти, противится Божьему повелению». (Рим. 13, 1-2) Посмотри на это и вдумайся: кто противится власти - противится Богу; а кто противится Богу - тот именуется отступником, а это наихудшее из согрешений. А ведь сказано это обо всякой власти, даже о власти, добытой кровью и войнами. Вдумайся в сказанное, ведь мы не насилием добыли царства, тем более поэтому, кто противится такой власти - противится Богу» ${ }^{15}$.

Итак, всякий бунт - сопротивление или ослушание власти, тем более православного властителя - сущий грех и отступничество от веры христианской. Но автор допускает исключение: «и все Божественные Писания наставляют в том, что дети не должны противиться родителям, а рабы господам ни в чем, кроме веры» ${ }^{16}$. Именно этот единичный случай оправдывает непослушание опального князя, который на его основании не признает Грозного православным царем. Он и выступает популяризатором определения опричнины как сатанинского полчищза, выводя его из синонимического значения слов «опричь» и «кроме». Называя опричников «кромешниками», Курбский отсылает читателя к евангельскому словосочетанию «кромешная тьма» (ср. Мт 22, 13) относящемуся к «царству сатаны», которое располагается кроме (вне) Божьего царства света ${ }^{17}$. Неслучайно в Псковской летописи, составляемой в Псково-Печерском монастыре при игумене Корнилии, преподобномученике, обезглавленном Грозным за переписку с беглым в Литву Курбским, Ивана Грозного именуют антихристом ${ }^{18}$.

Аргументация обоих сторон полемики строится на основании существенных, вероисповедных вопросов. Грозный выступает здесь как поборник истинной

15 Первое послание Ивана Грозного Курбскому, Подг. текста Е. И. Ванеевой и Я. С. Лурье, перев. Я. С. Лурье и О. В. Творогова, комм. Я. С. Лурье, Библиотека литературы Древней Руси, РАН. ИРЛИ; Под ред. Д. С. Лихачева, Л. А. Дмитриева, А. А. Алексеева, Н. В. Понырко. т. 11: XVI век, Санкт-Петербург 2001, Электронные публикации Института русской литературы (Пушкинского дома) $P A H$, http://lib.pushkinskijdom.ru/Default.aspx?tabid=9106, дост. 18.11.2015.

16 Там же.

17 Ср. С. Веселовский, Обзор мнений историков..., с. 191-192.

${ }^{18}$ Ср. С. Фомин, Правда о первом русском царе: Кто и почему искажает образ Государя Иоанна Васильевича (Грозного), Москва 2010, с. 149. 
веры, составная часть которой (согласно его убеждению) - это царская власть, отличная по природе от государственной власти неправославных стран, во власть которых отдает себя адресат послания. Присутсвие православной власти самодержца автор считает исключительной благодатью, которая воссияла лишь в его царствии.

Иван Грозный в начале послания приводит имя св. равноап. Константина Великого, как основоположника христианской власти: «Богом нашим Иисусом Христом дана была единородного слова Божия победоносная и вовеки непобедимая хоругвь - крест честной первому из благочестивых царю Константину и всем православным царям и хранителям православия» ${ }^{19}$.

Вторично имя императора Константина появляется как пример жестокости святых царей - это служит оправданию самого главного, негативного аспекта царской власти - как сторожа христианского порядка: «Вспомни величайшего из царей, Константина: как он ради царства сына своего, им же рожденного, убил! ${ }^{20}$.

Но сознание преемственности царской власти не мешает первому русскому царю в конечном счете отречься от византийской симфонии, считая ее главной причиной падения Второго Рима: «Нигде ты не найдешь, чтобы не разорилось царство, руководимое попами. Тебе чего захотелось - того, что случилось с греками, погубившими царство и предавшимися туркам?»²1.

Как ядро аргументации о недопустимости всякого ограничения Церковью царского самодержавия выступает в послании идея разделения призваний: «(...) одно дело - спасать свою душу, а другое дело - заботиться о телах и душах многих людей; одно дело - отшельничество, иное - монашество, иное - священническая власть, иное - царское правление» ${ }^{22}$.

В различии призваний и противопоставлении личного спасения духовному и физическому попечению о других, которые накладывает на плечи царя его особое призвание, мы находим оправдание для подмена соборной, многосозвучной, полифанической СИМ-фонии монотонным САМО-державием. Иное учение мы находим у Святых Отцов, хотя бы в Лествице, где все призваны в монастырь, как в духовную врачебницу 23 . Также уход старца-отшельника в пустыню и его возвращение с тем, чтобы окормлять людей, явно не соответствуют этой новой модели. В связи с ней возникает вопрос о смысле принятия Грозным царём великой схимы на смертном одре.

\footnotetext{
19 Первое послание Ивана Грозного Курбскому...

20 Там же.

21 Там же.

22 Там же.

${ }^{23}$ Ср. напр. Иоанн Лествичник, Лествица или Скрижсали духовные, Слова 18-19, Азбука веры, Святоотеческая библиотека, http://azbyka.ru/otechnik/?Ioann Lestvichnik/lestvitsa-ili-skrizhalidukhovnye=32, дост. 20.11.2015.
} 
Георгий Федотов, осмысляя факт убиения священномученика Филиппа, встает перед дилеммой: был ли это личный грех расшатавшегося морально Ивана или следствие провозглашенной им идеологии власти? В итоге он приходит к выводу, что мученическую смерть первоиерарха Московской Церкви мы должны принимать как проявление извращения теократической идеи православия. В конце концов все виновники этой жертвы были наказаны судьбою, но:

«Самая жестокая кара выпала на долю [Грозного] царя. Он видел крушение всех великих дел столь славно начавшегося царствования (...) Терзаемый то бесплодным раскаянием, то припадками звериной жестокости и сладострастия, преждевременно одряхлевший, казалось, он вкусил ад при жизни» ${ }^{24}$.

Приведенное определение наказания, которое еще в сей жизни достигло самодержавного царя, не допускающего возможности суда над собою, весьма сходно с последним кадром известного фильма Павла Лунгина ${ }^{25}$. Царь в одиночестве сидит среди зимней, вьюжной ночи за столом, на котором подготовлен большой пир. Опричник бьет в колокола, хриплым голосом призывая народ: «Выходи на Государево веселье!». Несчастный тиран в недоумении смотрит на опустошенный город и задает безответный вопрос: «Где мой народ?» И будто себе в ответ произносит: «Боже, милостив буди мне грешному». В своем грозном самодержавии остается он одиноким, лишь голодный, черный пёс откликается на царский призыв, вместо замученного народа ${ }^{26}$. В связи с легендой о кирпиче, упавшем на голову Грозного во время осмотра новопостроенного собора Вологодского кремля, имевшей подтверждение в летописи XVI в. ${ }^{27}$, Александр Быков предполагает возможность покушения на жизнь царя. В порыве гнева Иоанн IV велел уничтожить церковь и, хотя удалось отговорить его от этого намерения, но все-таки вплоть до его кончины не было дано разрешение освятить храм. Только при государе Феодоре Иоанновиче церковь освятили, но как ни странно - не в честь Успения Пресвятой Богородицы, как первоначально предполагалось, а Св. Софии. Вологодский историк объясняет это негласной местью народа за унижение Великого Новгорода и поругание его главного храма ${ }^{28}$.

Наконец нам следует поставить самый главный вопрос, в чем суть трагедии Ивана Грозного, первого русского царя? Почему ни история, ни Церковь, ни

${ }^{24}$ Г. Федотов, Святой Филипп, митрополит Московский., Собрание сочинений в двенадияати томах, т. III, Москва 2000, с. 94-95.

${ }_{25}$ См. П. Лунгин, Царь (фильм), 2009.

${ }^{26}$ Там же.

${ }^{27}$ См. Вологодский летописеи. Годы 1545, 1565, 1566, 1568, 1569, 1571, 1584 // Вологодские Епархиальные Ведомости. - 1873. - № 8-10, https://www.booksite.ru/ancient/history/32.htmб, дост. 20.11.2015

${ }^{28}$ Ср. А. Быков, Ивану Грозному была уготована в Вологде смерть, История Вологды, http://www.booksite.ru/ancient/history/58.htm, дост. 20.11.2015. 
православный народ, в своем большинстве, не признают правды за ним, даже если в собственных намерениях, как он пишет, думал только о благе ввереных ему христиан и готов был: «пострадать ради них в борьбе с врагами не только до крови, но и до смерти» 29.

Нам представляется, что суть личной трагедии Иоанна IV и несостоятельность возложенных на него надежд заключается в ослушании наставлений свтятогорского Старца, который предостерегал, что симфония неосуществима без синергии. Без личного преображения каждого члена соборного тела православной теократии - идея Третьего Рима незбыточна. Ибо происходит отчуждение государственной власти от закона любви и подмена его идеологией псевдохристианской власти ${ }^{30}$. Уместно, кстати, будет привлечь любимый в среде исихастов образ круга прп. Дорофея:

«Представьте себе круг, средину его - центр, и из центра исходящие радиусы лучи. Эти радиусы чем дальше идут от центра, тем более расходятся и удаляются друг от друга; напротив чем ближе подходят к центру, тем больше сближаются между собою. Положите теперь, что круг сей есть мір, самая средина круга - Бог, а прямые линии (радиусы), идущие от центра к окружности, или от окружности к центру, суть пути жизни людей. И тут то же. На сколько Святые входят внутрь круга к средине оного, желая приблизиться к Богу, на столько по мере вхождения они становятся ближе и к Богу, и друг к другу; и притом так, что сколько приближаются к Богу, столько приближаются и друг к другу, и сколько приближаются друг к другу, столько приближаются и к Богу. - Так разумейте и об удалении. Когда удаляются от Бога и обращаются ко внешнему, то очевидно, что в той мере, как они отходят от средоточия и удаляются от Бога, в той же мере удаляются и друг от друга, - и сколько удаляются друг от друга, столько удаляются и от Бога. Таково и свойство любви: на сколько мы находимся вне и не любим Бога, на столько каждый удален и от ближнего. Если же возлюбим Бога, то сколько приближаемся к Богу любовью к Нему, столько соединяемся любовью и с ближними, и сколько соединяемся с ближними, столько соединяемся и с Богом» ${ }^{31}$.

\section{Библиография}

Быков А., Ивану Грозному была уготована в Вологде смерть, История Вологды, http:// www.booksite.ru/ancient/history/58.htm.

Веселовский С., Московское государство $X V-X V I I$ вв. Из научного наследия, Москва 2008.

29 Первое послание Ивана Грозного Курбскому...

30 Преподобный Максим Грек, Духовно-нравстренные слова, Слово XXVIII..., с. 313-316

31 Подвижнические наставления св. Аввы Дорофея, Слово 42, Библиотека Якова Кротова, http://krotov.info/acts/06/3/dorofey.htm, дост. 20.11.2015. 
Житие и чудеса прп. Нила Сорского в списках XIX в., подг. текстов Г.М. Прохорова [в:] Преподобные Нил Сорский и Иннокентий Комельский. Сочинения, Изд. подг. Г. Прохоров, Санкт-Петербург 2005.

Иоанн Лествичник, Лествица или Скрижсали духовные, Слова 18-19, Азбука веры, Святоотеческая библиотека, http://azbyka.ru/otechnik/?Ioann_Lestvichnik/lestvitsaili-skrizhali-dukhovnye.

Kowalska H., Kultura staroruska. Tradycja i zmiana, Kraków 1998.

Kuffel J., Hezychazm Rusi Moskiewskiej; Metoda interpretacji na podstawie wybranych zabytków literatury przekładowej i oryginalnej, Kraków 2013.

Лунгин П., Царь (фильм), 2009.

Максим Грек, преподобный, Духовно-нравстренные слова, Свято-Троицкая Сергиева Лавра 2008.

Первое послание Ивана Грозного Курбскому, Подг. текста Е. И. Ванеевой и Я. С. Лурье, перев. Я. С. Лурье и О. В. Творогова, комм. Я. С. Лурье, Библиотека литературы Древней Руси, РАН. ИРЛИ, под ред. Д. С. Лихачева, Л. А. Дмитриева, А. А. Алексеева, Н. В. Понырко, т. 11: XVI век, Санкт-Петербург 2001, Электронные публикации Института русской литературы (Пушкинского дома) PAH, http://lib. pushkinskijdom.ru/Default.aspx?tabid=9106.

Подвижнические наставления св. Аввы Дорофея, Слово 42, Библиотека Якова Кротова, http://krotov.info/acts/06/3/dorofey.htm.

Прохоров Г., Исихазм и общественная мысль в Восточной Европе в XIV в., Tруды Omдела древнерусской литературы, т. 23, Электронные публикации Института русской литературы (Пушкинского дома) $P A H$, http://lib.pushkinskijdom.ru/Default. aspx?tabid=8453.

Федотов Г., Святой Филипп, митрополит Московский, Собрание сочинений в двенадияти томах, т. III, Москва 2000.

Фомин С., Правда о первом русском ијаре: Кто и почему искажает образ Государя Иоанна Васильевича (Грозного), Москва 2010.

Хоружий С., Исихазм и «политический исихазм»: к уточнению понятий, Институт Синергийной Антропологии, Библитека, http://synergia-isa.ru/wp-content/uploads/2012/05/ hor_polit_isikhasm.pdf. 